\title{
Media relations jako forma komunikacii marketingowej biblioteki
}

\section{Wprowadzenie}

Ś rodki masowego przekazu mogą mieć znaczący wpływ na opinię o bibliotece, funkcjonującą w jej bezpośrednim i dalszym otoczeniu. Dlatego utrzymywanie dobrych i częstych relacji z mediami może bardzo pozytywnie wpływać na wizerunek biblioteki, a także powodować wzrost zainteresowania jej działalnością i ofertą. Ponieważ biblioteki zazwyczaj nie są traktowane przez media jako atrakcyjny partner, przed pracownikami bibliotecznych działów public relations i rzecznikami prasowymi bibliotek stoi trudne zadanie przedstawienia biblioteki jako instytucji ciekawej, mogącej zainteresować odbiorców programów informacyjnych i prasy.

Współpraca z mediami, czyli tzw. media relations, jest jednym z instrumentów public relations (dalej: PR), którego celem jest przedstawienie w mediach informacji o bibliotece, tak aby zainteresować otoczenie jej działalnością, usługami oraz stworzyć pozytywny wizerunek i wykreować korzystną opinię. Utrzymywanie kontaktów z mediami jest niekiedy określane terminem publicity, czyli „bezpłatnym rozpowszechnianiem określonych wiadomości wspierających interesy organizacji przy wykorzystaniu mediów masowych"1. Jednakże przyjmuje się, że działania publicity $\mathrm{w}$ większym stopniu niż media relations są skupione na uzyskaniu rozgło-

${ }^{1}$ A. Żbikowska, Public relations, Warszawa 2005, s. 88. 
su za wszelką cenę (często przy ograniczeniu przekazywanych informacji do wyłącznie pozytywnych, z pominięciem informacji negatywnych), są nastawione na działania sensacyjne, nie zawsze do końca prawdziwe. Ponadto publicity w większym stopniu jest działalnością stricte informacyjną, w mniejszym zaś skupioną, tak jak media relations, na tworzeniu stałego i trwałego dialogu z otoczeniem ${ }^{2}$. Zgodnie z definicją, media relations to nawiązywanie współpracy z przedstawicielami środków masowego przekazu. To także: „stałe pielęgnowanie stosunków z dziennikarzami, żmudne budowanie baz danych i sieci powiązań, organizowanie interesujących z punktu widzenia mediów imprez, wyszukiwanie bądź kreowanie ciekawych informacji oraz upowszechnianie ich we właściwej formie”3. Uważa się, że pracownicy zajmujący się PR lub media relations nie powinni jednocześnie pełnić funkcji rzecznika prasowego biblioteki, którego podstawowym zadaniem jest przede wszystkim reprezentowanie interesów instytucji, w mniejszym zaś dbanie o trwałe i ścisłe relacje z otoczeniem ${ }^{4}$.

\section{Media wspótpracujące z biblioteką}

B iblioteki, które chcą skutecznie promować swój wizerunek w mediach, Bnie powinny ograniczać się do biernego oczekiwania na ich zainteresowanie. Dlatego też biblioteczne działy PR, pragnące regularnie współpracować z przedstawicielami wybranych środków masowego przekazu, tworzą listy dziennikarzy zainteresowanych informacjami o ich instytucji i takie dane regularnie im przekazują. Lista powinna zawierać kontakty nie tylko do poszczególnych redakcji, ale również dane, jakim typem informacji może być zainteresowana konkretna redakcja, z którym dziennikarzem można kontaktować się $\mathrm{w}$ razie potrzeby oraz $\mathrm{w}$ jakiej formie powinny być przygotowane przez bibliotekę materiały. Żelazną regułą, niezależnie od wybranego medium, w którym zostanie opublikowana informacja, jest przygotowywanie materiałów ciekawych, przyciągających uwagę, które mają szansę zostać zapamiętane przez czytelników, widzów czy słuchaczy.

${ }^{2}$ K. Wójcik, Public relations. Wiarygodny dialog z otoczeniem, Warszawa 2005, s. $145-148$.

3 B. Rozwadowska, Public relations. Teoria, praktyka, perspektywy, Warszawa 2002, s. 143.

${ }_{4}^{4}$ Public relations - narzędzia przyszłości, pod red. T. Solińskiego, D. Tworzydło, Rzeszów 2007, s. 241. 
Do najważniejszych mediów, z którymi mogą współpracować biblioteki, są zaliczane:

1. Radio - uznawane za najszybsze źródło informacji. Jego podstawową zaletą jako przekaziciela informacji PR bibliotek jest stosunkowo długi czas emisji przekazu przy równoczesnym zachowaniu wysokiego wskaźnika słuchalności. W przypadku jednak, kiedy przedstawiciel biblioteki bierze aktywny udział $\mathrm{w}$ audycji, musi charakteryzować się określonym zestawem cech, takich jak swoboda wypowiedzi, erudycja, poprawna wymowa itp. Ponadto, aby skutecznie skonstruować formę przekazu, powinien wcześniej poznać charakter programu oraz orientować się, do kogo ten program jest adresowany, a więc jaka grupa słuchaczy będzie jego odbiorcami.

2. Telewizja - jest najatrakcyjniejszym medium z punktu widzenia działań PR, ponieważ charakteryzuje się największą siłą oddziaływania. Z jednej strony - ma liczną grupę widzów, z drugiej zaś - fonia wsparta jest bardzo atrakcyjną formą wizualną. Bardzo często telewizja pozostaje jednak poza możliwościami emisyjnymi bibliotek, choć zdarzają się przykłady udanej współpracy placówek bibliotecznych z lokalnymi nadawcami lub atrakcyjnie przygotowane przez bibliotekarzy materiały wyemitowane w ogólnopolskich programach informacyjnych. Zwykle przedstawienie materiału w telewizji jest dla bibliotek bardzo trudne i pracochłonne, wymaga wielu zabiegów i starań, dlatego udaje się to tylko niektórym placówkom, ale też korzyści z obecności biblioteki w tym medium są znaczne. Do najczęstszych form przekazywania informacji o bibliotekach w mediach należą wzmianki w programach informacyjnych oraz wywiady z pracownikami bibliotek lub innymi osobami z nimi związanymi.

3. Prasa:

- prasa codzienna (dzienniki);

- prasa społeczno-informacyjna (tygodniki);

- prasa poświęcona wybranej tematyce (miesięczniki dla różnych grup odbiorców);

- prasa regionalna;

- prasa fachowa.

Prasa jest uznawana za najpowszechniejszego przekaziciela informacji w ramach public relations ${ }^{5}$. Początkowo większość działań

${ }^{5}$ Komunikacja marketingowa. Instrumenty i metody, pod red. B. Szymoniuk, Warszawa 2006, s. 119. 
PR skupiała się właśnie na kontaktach z prasą, nosząc miano press relations ${ }^{6}$. Prasa jako medium charakteryzuje się znaczną liczbą odbiorców oraz wysokim zaufaniem czytelników do informacji w niej publikowanej. Dzięki dużej różnorodności prasy (m.in. zróżnicowany profil tematyczny, zasięg geograficzny itp.) oraz jej większej, w stosunku do innych mediów, dostępności jest ona często wykorzystywana do działań PR przez rzeczników prasowych bibliotek oraz biblioteczne działy PR. Prasa, pomimo mniejszych niż pozostałe media możliwości szybkiej reakcji na wydarzenia, umożliwia przekazywanie bardziej szczegółowej i obszernej informacji.

4. Internet - zaletą umieszczania informacji w Internecie jest jej powszechna dostępność, tj. dla wszystkich, prawie w każdym miejscu i o dowolnej porze. Jednakże publikując informacje w Internecie, łatwo jest utracić nad nimi kontrolę, tj. mogą być one dowolnie kopiowane i odczytywane przez szeroką rzeszę ludzi, komentowane, a nawet zniekształcane i rozpowszechniane dalej w zmienionej formie. Nigdy nie wiadomo, jak wielki zasięg osiągnie przekaz internetowy, czy będzie nic nieznaczącą wzmianką, o której wkrótce wszyscy zapomną, czy też wywoła ogólne poruszenie i zostanie odczytany przez tysiące internautów. Dlatego nie można zapominać o niebezpieczeństwach Internetu przy publikacji jakichkolwiek danych.

\section{Metody wspólpracy z mediami}

$D^{\mathrm{s}}$ okonując wyboru medium, należy mieć na względzie, że nie zawsze jego duży zasięg będzie równoznaczny z zainteresowaniem odbiorców emitowaną informacją. Ważny jest bowiem charakter publikowanego przekazu oraz potencjalna grupa docelowa, do której miałby on dotrzeć. Czasem lokalne dzienniki lub mniejsze branżowe pisma mogą być bardziej skuteczne niż media ogólnokrajowe.

Do podstawowych metod współpracy z mediami najczęściej zalicza się:

- przekazywanie informacji prasowych;

- odpowiadanie na zapytania mediów;

${ }^{6}$ S. Black, Public relations, Kraków 2006, s. 66. 
- organizowanie konferencji prasowych;

- udzielanie wywiadów.

Informacje prasowe to wszelkiego typu materiały przygotowane przez bibliotekę, przekazane przedstawicielom środków masowego przekazu. Zalicza się do nich:

1. Bieżące informacje prasowe, czyli przekazy o aktualnej działalności biblioteki, imprezach przez nią organizowanych, realizowanych usługach, zmianach w funkcjonowaniu itp. Ich zadaniem jest bieżące informowanie otoczenia o funkcjonowaniu biblioteki i zachęcanie do skorzystania z jej usług.

2. Oświadczenia prasowe - prezentują stanowisko biblioteki i jej opinię w konkretnej sprawie. Im większa i bardziej aktywna w swych działaniach jest biblioteka, tym częściej może spodziewać się, że będzie proszona o wydawanie oświadczeń dla prasy. Dobrze, aby biblioteka była przygotowana na wydanie takiego oświadczenia, zwłaszcza jeżeli poruszany problem ma kontrowersyjny charakter. Przykładem tematu, który budził swego czasu sporo emocji, a który wymagał oświadczenia prasowego jednej z bibliotek, było zapytanie mediów o posiadane w jej zbiorach książki oprawiane w ludzką skórę. Część z bibliotek decyduje się na utworzenie w ramach swojej struktury organizacyjnej etatu rzecznika prasowego ${ }^{7}$. Według przeprowadzonych przez autorkę badań, obecnie stanowisko takie istnieje w około $6 \%$ polskich bibliotek ${ }^{8}$.

3. Opracowania specjalistyczne - są sporządzane na potrzeby konkretnych audycji, portali internetowych lub też czasopism fachowych. Stanowią profesjonalne opracowanie zagadnienia, w zakresie którego pracownicy biblioteki posiadają kompetencje merytoryczne. Tego typu opracowania nie zawsze są bezpośrednio związane z działalnością biblioteki, jednakże w sposób pośredni informują otoczenie o jej istnieniu i ukazują bibliotekę jako instytucję godną zaufania, o wysokim poziomie i możliwościach.

4. Materiały gotowe do publikacji - są to materiały przygotowywane najczęściej na prośbę przedstawicieli mediów, które mają formę

7 R. Szczepaniak, Czy w bibliotece potrzebny jest rzecznik prasowy? Na podstawie doświadczeń polskich i niemieckich, [w:] Marketing biblioteczny: rozważania, dyskusje, konteksty, pod red. M. Wojciechowskiej, Gdańsk 2007, s. 51-58.

${ }_{8}$ Badania zostały przeprowadzone w latach 2007-2008 we wszystkich typach bibliotek na terenie Polski. 
niewymagającą dalszych zmian, poprawek czy uzupełnień, czyli gotową do publikacji. Tego typu materiały przygotowywane przez biblioteki bardzo często dotyczą imprez lub akcji przez nie organizowanych.

5. Tekst sponsorowany - polega na odpłatnej publikacji krótkiej notki lub artykułu o wcześniej ustalonej treści. Teksty sponsorowane są rzadkością w działaniach marketingowych bibliotek, które w miarę możliwości starają się korzystać z nieodpłatnych form publikacji medialnych.

Wszelkie materiały prasowe mogą być przekazywane w formie drukowanej, elektronicznej, materiałów ilustracyjnych (graficznych), nagrań dźwiękowych, materiału filmowego i in. Materiały udostępniane mediom, w zależności od potrzeby i możliwości, mogą przybierać różną formę. Mogą to być tzw. materiały robocze, z których dziennikarz sam przygotuje informację gotową do emisji, lub też materiały gotowe do publikacji, tj. np. opracowane w całości artykuły, notki informacyjne czy gotowe, zmontowane już filmy (tzw. video releases). Należy pamiętać, aby szczególnie zadbać o formę, stylistykę i opracowanie merytoryczne materiałów gotowych do publikacji przesyłanych mediom, ponieważ zdarza się, że takie materiały nie przechodzą już w redakcji żadnej korekty.

Odpowiedzi na zapytania mediów w środowisku bibliotek zdarzają się stosunkowo rzadko ze względu na niskie zainteresowanie opinii publicznej sprawami tego sektora. Jednakże jeśli pytania ze strony dziennikarzy już się pojawią, biblioteki powinny dbać o udzielenie szybkiej, konkretnej i merytorycznie wartościowej odpowiedzi, ponieważ publikowanie tego typu informacji wpływa zawsze na podniesienie prestiżu bibliotek i wzrost zainteresowania nimi.

Organizowanie przez biblioteki konferencji prasowych nie jest częstym działaniem. Powodem tego jest nierzadko brak na tyle atrakcyjnych, a raczej sensacyjnych tematów spotkań, by media były zainteresowane przyjazdem na konferencję. Konferencje prasowe mają jednak wiele zalet, z których bibliotekarze powinni sobie zdawać sprawę. Należą do nich m.in. możliwość przekazania dziennikarzom znacznie obszerniejszych materiałów niż w przypadku innych form kontaktu, w znacznie ciekawszej formie (np. za pomocą pokazu, filmu, prezentacji itp.), możliwość odpowiedzi na pytania dziennikarzy i w związku z tym bardziej dogłębne przedstawienie zagadnienia oraz możliwość zaprezentowania samej biblioteki, jeśli konferencja w niej właśnie się odbywa. Ponadto wi- 
zyta przedstawicieli mediów w siedzibie biblioteki zawsze pozostawia głębsze wrażenia niż odczytanie notatki prasowej, co może zaowocować częstszym poruszaniem spraw biblioteki lub nawet nawiązaniem dłuższej współpracy. Organizacja konferencji prasowych wymaga jednak pewnego wysiłku związanego z ich przygotowaniem, np. z zapewnieniem miejsca, w którym będzie się odbywać impreza, wysłaniem zaproszeń itp.

Udzielanie wywiadów przez przedstawicieli bibliotek ma najczęściej charakter z góry zaplanowanego spotkania, na którym są omawiane zagadnienia według przyjętego wcześniej scenariusza lub też zaakceptowanego przez obie strony zakresu tematycznego.

\section{Monitoring mediów}

W praktyce media relations, w celu jak najskuteczniejszej współpracy z wybranymi mediami, stosuje się tzw. monitoring mediów ${ }^{9}$. Jego zadaniem jest analiza publikowanych informacji oraz zbieranie danych na temat jej odbiorców. Na podstawie wspomnianej analizy biblioteka może nawiązać współpracę z tymi mediami, na których adresatów chce wpłynąć bądź zainteresować ich emitowanymi przez siebie informacjami. Ponadto monitoring mediów umożliwia uzyskanie danych na temat aktualnego wizerunku biblioteki. Pozwala określić, jak jej działalność jest oceniana przez środki masowego przekazu, czy jej funkcjonowanie jest dostrzegane przez lokalną i dalszą społeczność, czy też jest instytucją niezauważaną, o której nie pisze się nic lub pisze i mówi się niewiele. Firmy komercyjne bardzo często przeprowadzają monitoring mediów za pośrednictwem wyspecjalizowanych agencji, które wyniki swojej pracy przesyłają e-mailem, pocztą tradycyjną lub udostępniają po zalogowaniu w serwisie, oferując nierzadko poza wycinkami prasowymi również nagrania audycji. Jednak w przypadku bibliotek badania te wykonują działy PR lub - w sytuacji, kiedy w strukturze organizacyjnej nie występuje jednostka wyspecjalizowana w tym kierunku - pracownicy odpowiedzialni za reklamę i promocję biblioteki.

Przeprowadzone przez autorkę badania wykazały, że w Polsce zaledwie w 18\% bibliotek istnieje komórka organizacyjna lub dział do spraw PR. Zdecydowanie najczęściej, bo wśród 44\% bibliotek, działania te nale-

9 D. Tworzydło, Public relations. Teoria i studia przypadków, Rzeszów 2005, s. 33. 
żą do obowiązków dyrektora lub kierownika, 17\% bibliotek ma w swojej strukturze wyodrębnione stanowisko do spraw PR, a 11\% cały dział wykonujący tego typu zadania. $6 \%$ bibliotek działania PR realizuje za pośrednictwem działu marketingu i również 6\% ma swojego rzecznika prasowego. Żadna z bibliotek, która uczestniczyła w badaniu, nie zatrudniała specjalistycznej firmy PR. Jest to zapewne związane z wysokimi kosztami takich usług. Bardzo pozytywne jest jednak zjawisko badania wizerunku bibliotek. Niemal wszystkie placówki, w tym również i te, które nie prowadzą działań PR, wykonują badania swojego wizerunku. Różnice występują jedynie jeśli chodzi o częstotliwość tych badań. Najczęściej, bo aż w 59\% bibliotek, są one prowadzone raz do roku, w 28\% raz na 2-3 lata, w $11 \%$ raz na 5 lat, a w $2 \%$ - rzadziej niż co 5 lat.

\section{Wskaźniki oceny skuteczności mediów}

D obór mediów, z którymi współpracuje biblioteka, jest zależny od dwóch najważniejszych wskaźników: ilościowych i jakościowych. Wskaźniki ilościowe pokazują, jaki zasięg może uzyskać informacja publikowana w wybranym medium, czyli ile osób odczyta lub odsłucha przekaz, tj. wysłucha audycji radiowej, obejrzy program telewizyjny czy też dokona odsłony strony WWW. Same wskaźniki ilościowe nie zapewniają jednak miarodajności pomiaru. Niezbędne jest uwzględnienie wskaźników jakościowych, mówiących o możliwym wpływie przekazu na jego odbiorców. Ponieważ nie każdy komunikat opublikowany w mediach jest jednakowo skuteczny, biblioteka pragnąca efektywnie nawiązywać kontakty ze swoim otoczeniem musi dokonać wyboru mediów i umieszczać informacje $w$ tych $\mathrm{z}$ nich, które będą odbierane przez osoby potencjalnie zainteresowane komunikatem. I tak np. informacji o zajęciach dla przedszkolaków w bibliotece publicznej nie warto zamieszczać w czasopiśmie dla nastolatków, a artykułu o nowo zakupionych przez bibliotekę akademicką bazach danych z zakresu nauk humanistycznych w czasopiśmie czy audycji dla matematyków. W zależności od wybranego medium są stosowane różne warianty jakościowych i ilościowych wskaźników. Przykładowe $\mathrm{z}$ nich to:

1. Wskaźniki dla przekazów radiowych:

- możliwość odbioru stacji;

- procent wszystkich odbiorców słuchających danej stacji; 
- procentowy udział czasu poświęconego na słuchanie danej stacji w stosunku do czasu przeznaczonego na słuchanie innych rozgłośni;

- odsetek słuchaczy stacji mających kontakt z jej programem;

- odsetek odbiorców słuchających wyłącznie jednej stacji lub jednego programu;

- średni czas odsłuchiwania stacji w ciągu określonego przedziału czasu.

2. Wskaźniki dla przekazów telewizyjnych:

- liczba gospodarstw domowych mająca możliwość odbioru danej stacji;

- oglądający daną stację wśród ogółu oglądających telewizję w analizowanym czasie;

- średni czas oglądania danego programu;

- oglądalność minutowa, czyli wielkość widowni, jaka w danej minucie oglądała konkretny kanał telewizji.

3. Wskaźniki dla przekazów prasowych:

- częstotliwość ukazywania się tytułu;

- nakład tytułu;

- nakład sprzedany;

- średnia liczba osób czytająca ten sam egzemplarz czasopisma.

4. Wskaźniki dla przekazów internetowych:

- liczba odwiedzin danej strony internetowej w określonym przedziale czasowym;

- liczba kliknięć w baner reklamowy ${ }^{10}$.

Do wskaźników efektywności działań PR niezwiązanych z konkretnym medium można zaliczyć również: liczbę odwiedzin czytelników, liczbę zapytań w formie bezpośredniej, telefonicznej czy mailingowej oraz zmiany zachowań społecznych, jeżeli biblioteka promowała swoimi działaniami zmianę postaw, np. prowadziła akcję popularyzacji czytelnictwa.

Poza wskaźnikami o charakterze ilościowym i jakościowym występują również wskaźniki ekonomiczne określające opłacalność zamieszczania przekazu, tj. koszt dotarcia do odbiorców informacji. Wskaźniki te są jednak niezwykle rzadko stosowane przez biblioteki, które skupiają się na zamieszczaniu informacji w tych mediach, które nie pobierają opłat za publikację materiału.

${ }_{10}$ Zob. K. Wójcik, dz. cyt., s. 473-479, oraz Public relations $w$ teorii i praktyce, pod red. B. Ociepki, Wrocław 2003, s. 124. 
W krajach anglosaskich, w stosunku do całości działań PR, przyjęto model oceny skuteczności składający się z analizy czterech podstawowych płaszczyzn oddziaływania, do których należą:

- output - efekt osiągnięty w mediach;

- outgrowth - efekt bezpośredniego działania na grupy docelowe: percepcji, zrozumienia, zapamiętania przekazu itp.;

- outcome - efekt pośredniego działania na grupy docelowe: stopień zmiany postaw, zachowania, poglądów itp.;

- outflow - efekt ekonomiczny ${ }^{11}$.

Niezależnie od wyników monitoringu mediów należy uwzględniać siłę wpływu mediów, który jest proporcjonalnie większy niż wpływ wywierany przez osoby prywatne. Jest to tzw. zjawisko zwielokrotnienia. Środki masowego przekazu często są uznawane za swoistych liderów opinii, a ponadto są narzędziem służącym do publikowania opinii tychże liderów. Liderów opinii dzieli się na liderów formalnych, szanowanych ze względu na zajmowaną pozycję czy funkcję, do których należą m.in.: politycy, nauczyciele, naukowcy, księża oraz dziennikarze, jak również liderów nieformalnych, którzy są cenieni ze względu na swoją charyzmę, wyznawane wartości moralne, wiedzę, doświadczenie itp. Według Sama Blacka, „zmiana postaw lub przekonań lidera opinii jest potęgowana przez jej wpływ na inne grupy odbiorców. Szacuje się, że poglądy $10 \%$ osób (liderów opinii) w znacznym stopniu kształtują poglądy pozostałych 90\% odbiorców przekazu"12.

\section{Podsumowanie}

Współpraca biblioteki z mediami jest niewątpliwie bardzo cenna i ma szeroką gamę zalet. Każda biblioteka, niezależnie od typu czy wielkości, powinna zabiegać o to, aby w mediach pojawiało się o niej jak najwięcej korzystnych informacji. Jednakże warto podkreślić również, że środki masowego przekazu mogą zniekształcić informacje uzyskane od bibliotekarzy, potraktować je wybiórczo, przeinaczyć lub celowo zmienić, aby uatrakcyjnić publikowany materiał. Nierzadko zdarza się także przedstawianie informacji wyjętych z kontekstu lub też zwykłe pomyłki, które jednak niewarte są podejmowania działań mających na celu sprostowanie błędu.

\footnotetext{
11 Public relations - narzędzia przyszłości..., s. 93.

12 S. Black, dz. cyt., s. 54.
} 
Również przed rzecznikami prasowymi bibliotek i bibliotecznymi działami PR pojawiają się nowe wyzwania. Bibliotekarze muszą nauczyć się efektywnie współpracować z mediami oraz starać się wykorzystywać możliwości, które one oferują, w celu poprawy wizerunku i spopularyzowania oferty bibliotek. Umiejętnie praktykowane media relations może przyczynić się do wielu sukcesów w działalności instytucji bibliotecznych.

\section{Media relations as a marketing communication method for library} Abstract

Public relations is a current issue not only in management of firms and business organizations, but also in library management. These activities help the library create positive image and built appropriate relations between users and librarians. In the paper there is introduced the media relations problem as an example method of marketing and public relations. The terms media relations and publicity as well as media types which can be used by libraries to build their image and to promote services are characterized. There is also presented data about creation of departments and positions in Polish libraries which purpose is to collaborate with mass media. 